\title{
Editorial preface
}

\author{
R. L. Hall
}

Published online: 6 March 2015

(C) Springer Science+Business Media Dordrecht 2015

The essays in this issue exhibit a kind of continental drift, or at least embody a direction of inquiry that diverges (slightly) from the usual analytic approach to the philosophy of religion. Two articles discuss the latter Wittgenstein, one Caputo and Heidegger, and one brings Charles Taylor, Freud, and Jung into the discussion. And even the essay that seems more easily to align with the strict analytic approach focuses on returning "faith" to ordinary usage, to its connection with acceptance rather than propositional assent.

The first of the two essays that explore the relevance of the later Wittgenstein for the philosophy of religion, is about concept formation, and more particularly about how religious concepts are formed. Randy Ramal discusses differences in the formation of empirical concepts and distinguishes this causal process of formation from what he calls the regulative formation of religious concepts.

Ramal points out, for example, that because it is an empirical fact that humans are sexual beings, it was inevitable that humans would form a concept of sexuality. But it was not inevitable that human beings would form the same view of it, or agree on what the correct view of it is, or agree on the correct attitude to take towards it. We can see the contingency of these views of sexuality when we consider, for example, the radical differences between the way that the ancient Egyptians viewed it and the way that St. Augustine viewed it.

Following Wittgenstein, Ramal thinks that the philosophical project, as opposed to the scientific project, is to focus on concept formation as a regulative not a causal process. In this regulative process, concepts are formed, that is constituted, on the basis of the roles they play in the concrete practices of human beings. Once we realize this, it is easy to see that religious concepts are formed in a similar way: they

R. L. Hall (两)

Stetson University, Deland, USA

e-mail: ronhall@stetson.edu 
are constituted in our specific religious practices such as worship and prayer. However, Ramal insists that even though the formation of some empirical concepts is causally inevitable, and the formation of religious concepts is not, this is no reason to think that the former give us a better picture of the world than the latter; indeed quite to the contrary.

In the second essay, Hermen Kroesbergen defends D.Z. Phillips' defense of Wittgenstein's idea that the proper business of the philosopher is not to advance theses, or to advocate for this or that position as true of false, but to clarify our concepts and dispel conceptual confusion. But Phillips has been criticized for failing to keep these projects properly separated. His critics say that his efforts to distinguish superstition from genuine religious practice turns into a project of advocating for his own preference as to what a genuine religious practice is while condemning superstition.

Kroesbergen, however, defends Phillips on this matter. His argument hinges on seeing that just because a term is essentially normative it does not follow that a description or clarification of it must also be normative. Consider the distinction between genuine and fake friendship. We can describe what we mean by either without advocating for either in a specific case. There is always room for wondering if the person I take to be my genuine friend is or is not really so. But this is not to wonder what we mean by "genuine friend." As Wittgenstein has told us, it is what human beings say that is true or false, they agree in the language they use. That is, I may say that he or she is a fake friend and you may disagree, but we might well agree, upon discussion, what we mean by "fake friend." By analogy, we may say that this practice is superstition or not, but we can do so only if we have a clear idea of what counts as superstition and what counts as a genuine religious practice. It is the business of philosophy to render these conceptual clarifications. Phillips did not abandon this philosophical project.

In our next essay, the bearing on the usual issues in the philosophy of religion is indirect. Sylvie Avakian argues that John Caputo's concept of undecidability leaves out an indispensable element in the human search for meaning. That element is found in Heidegger's concept of anticipatory resoluteness. Avakian thinks that Caputo and Heidegger are right to resist the backwards-looking metaphysics of presence (in Plato and all of the subsequent footnotes to his logocentricsm) and to favor the importance of a forward-looking perspective in which all claims to stability and security are subject to being overturned. However, she thinks Caputo was wrong to claim that Heidegger fell into the very metaphysics of presence he was trying to overturn.

Avakian argues that Caputo's mistake was to think that Heidegger's emphasis on the need for a recovery from the metaphysics of presence, his anticipatory resoluteness, or inward decision, implies the achievement of a security and stability (Glassenheit) that radical undecidability refuses, and he should have refused as well. But Avakian argues that deconstruction and recovery are complementary and not contradictory. Her analysis opens the way for the Christian to move forward by deconstructing every expression of inauthenticity and nevertheless freely finding some authentic and ongoing resolutions to questions of the self and God. 
In "Faith and Trust," our next essay, Benjamin McCraw argues that the ordinary assumption that religious faith involves trust in God is in need of philosophical clarification. After discussing essential elements in epistemic trust, McCraw makes the case for distinguishing between religious faith and trust. He argues that faith is a more profound concept than epistemic trust. He comes to this conclusion by first providing an analysis of trust in general, what he calls epistemic trust. The upshot is his claim that faith includes epistemic trust but nevertheless is more than that trust. This means that religious faith is not merely a matter of trusting in God. That is, faith includes trust but also goes beyond it. Faith is not different from trust just because it has a religious content. Rather, the key difference is that trust involves entrenched beliefs while faith also involves entrenched attitudes, especially confidence and other emotional attitudes. When this is clarified, the ordinary assumption that faith involves trust is vindicated. As well, this conceptual analysis advances our philosophical understanding of the differences between religious faith and religious belief.

The final essay in this issue discusses Charles Taylor's endorsement of Mikhail Epstein's notion of “minimal religion" in Taylor's book, A Secular Age. In trying to come to terms with Taylor's endorsement, Ian Fraser argues that it fails. This is so because Epstein's notion of minimal religion is grounded in part in the work of Freud, whose vision of the unconscious is rejected by Taylor because he thought it was too closely tied to the immanent realm. If our future is to avoid this secular depreciation of the transcendent, and its correlative devaluation of religion, Taylor thought we must find a way to fullness that is open to the transcendent. If minimal religion is exclusively tied to Freud's approach, the transcendent is lost. But Epstein also grounds his notion of minimal religion to Jung's theory of the collective unconscious, something that Taylor does not mention. Had Taylor considered this, he might have been more justified in endorsing Epstein. To argue this, Fraser develops Jung's position to show that it could have been an efficacious source for achieving the dialogue Taylor was seeking to establish between humanism and theism, immanence and transcendence. 